THE objective of this study was to test the hypothesis that an oxidative stress can serve as a signal to regulate the expression of CCR5. When human monocytes were exposed to graded concentration of hydrogen peroxide $\left(\mathrm{H}_{2} \mathrm{O}_{2}\right)$, CCR5 mRNA levels increased maximally at $4 \mathrm{~h}$ of exposure to $200 \mu \mathrm{M}$ of $\mathrm{H}_{2} \mathrm{O}_{2}$ and decreased by $24 \mathrm{~h}$ of treatment. Pretreatment of monocytes with the NF-kB inhibitor BAY 118072 blocked the $\mathrm{H}_{2} \mathrm{O}_{2}$-induced augmentation of CCR5 mRNA expression, suggesting a role for this transcription factor in the regulation of CCR5 expression. CCR5 protein expression on the plasma membrane was also increased by treatment with $\mathrm{H}_{2} \mathrm{O}_{2}$, as assessed by flow cytometry. This was accompanied by enhanced responsiveness of $\mathrm{H}_{2} \mathrm{O}_{2}$-pretreated monocytes to the CCR5 ligand MIP-1 $\beta$ in terms of chemotaxis and c-fos gene activation. Our results suggest that oxidative stress may indeed modulate the expression of chemokine receptors and thus contribute to regulation of the inflammatory process.

Key words: Reactive oxygen species, Monocyte, Macrophage, c-fos, Chemotaxis

\section{Upregulation of expression of the chemokine receptor CCR5 by hydrogen peroxide in human monocytes}

\author{
Geneviève Lehoux, Christian Le Gouill, \\ Jana Stankova and Marek Rola-Pleszczynski ${ }^{\text {CA }}$
}

Immunology Division, Department of Pediatrics, Faculty of Medicine, Université de Sherbrooke, Sherbrooke, QC J1H 5N4, Canada

\author{
${ }^{\mathrm{CA}}$ Corresponding Author \\ Tel: +1 8193461110 , ext. 14851 \\ Fax: +1 8195645215 \\ E-mail: mrolaple@courrier.usherb.ca
}

\section{Introduction}

Recruitment of inflammatory cells to a tissue site is a complex process that depends in part on the local expression of appropriate chemoattractant proteins termed chemokines. The interaction of chemotactic factors with their corresponding receptors on leukocytes constitutes the basis for chemotaxis to inflammatory sites and cell activation. In addition to the production of chemotactic factors, the level of expression of their receptors on target cells will determine the magnitude of the response. CCR5 is a G-protein-coupled receptor that binds the chemokines monocyte inflammatory protein (MIP)$1 \alpha$, MIP-1 $\beta$ and RANTES. ${ }^{1,2}$ CCR5 is expressed on monocytes/macrophages, activated $\mathrm{T}$ cells and dendritic cells in lymphoid tissues, the ovaries and the lungs. ${ }^{3}$ It has been proposed to be implicated in several inflammatory diseases, such as rheumatoid arthritis, asthma and glomerulonephritis. $^{4-7}$

Inflammatory cells, such as macrophages and neutrophils, play an important role in host defense, but may also contribute to tissue injury through the release of reactive oxygen species (ROS). ${ }^{8-10}$ Increased production of ROS is now believed to be implicated in the pathogenesis of inflammatory disease such as acute respiratory distress syndrome, asthma, rheumatoid arthritis and AIDS. ${ }^{11-14}$ In addition, ROS are recognized as mediators of cell apoptosis. ${ }^{15-19}$ The role of the second messenger in signal transduction requires small, non-toxic concentrations of ROS that can be produced by every cell type. ROS have been shown to affect the production of the chemokine interleukin (IL)-8 in dendritic cells and monocytes, ${ }^{20,21}$ monocyte chemotactic protein (MCP)-1 in monocytes and MIP- $1 \alpha$ in the alveolar macrophages cell line NR8383. ${ }^{22}$ These effects may be mediated in part through the action of ROS on redox-sensitive proteins, such as the transcription factor nuclear factor (NF) $-\kappa B,{ }^{23-29}$ or some upstream protein kinases. ${ }^{30} \mathrm{NF}-\kappa \mathrm{B}$ regulates many of the genes involved in the immune response, including IL-2, IL6 , IL-8, interferon- $\gamma$, tumour necrosis factor (TNF)- $\alpha$, vascular cell adhesion molecule-1 and intracelular adhesion molecule- $1 .{ }^{31}$ It is a heterodimer of $50 \mathrm{kDa}$ (p50) and $65 \mathrm{kDa}(\mathrm{p} 65)$ subunits and is found in the cytoplasm in an inactive form, bound to the inhibitory protein I $\mathrm{KB}$ through the p65 moiety. ${ }^{32,33}$ In response to various stimuli, including proinflammatory cytokines, I $\kappa \mathrm{B}-\alpha$ is first phosphorylated by IKK and then rapidly degraded by the proteasome, allowing translocation of $\mathrm{NF}-\kappa \mathrm{B}$ to the nucleus and subsequent gene activation. ${ }^{34,35}$

The CCR5 gene promoter contains consensus binding sequences for the transcriptional activating factor NF- $\kappa \mathrm{B} .{ }^{36}$ In this study, we investigated the hypothesis that ROS can increase the expression of the chemokine receptor CCR5 in human monocytes and thus contribute in the inflammatory process. We show here that hydrogen peroxide $\left(\mathrm{H}_{2} \mathrm{O}_{2}\right)$, a cell membrane-permeable ROS, can indeed upregulate 
CCR5 expression in monocytes and increase their responsiveness to the CCR5 ligand MIP-1 $\beta$.

\section{Materials and methods}

\section{Chemical reagents}

$\mathrm{H}_{2} \mathrm{O}_{2}$ and dimethyl-sulfoxide were from Fisher Scientific (Fair Lawn, NJ, USA). MIP- $1 \beta$ was obtained from Pepro Tech (Rocky Hill, NJ, USA) and actinomycin D was from Merck Sharp \& Dohme International (Rahway, NJ, USA). BAY 11-7082 was from Calbiochem (San Diego, CA, USA) and catalase was from Sigma-Aldrich Chemie (Steinheim, Germany).

\section{Preparation of monocytes}

Human venous blood from healthy medication-free volunteers was collected on citrate/dextrose/adenine. The peripheral blood mononuclear leukocytes were enriched by dextran sedimentation, layered over a Ficoll-Hypaque cushion and centrifuged at $400 \times g$ for $20 \mathrm{~min}$. Mononuclear leukocytes were collected at the interface and washed twice with phosphate-buffered saline (PBS) and resuspended in RPMI 1640 medium with 10\% heat-inactivated fetal bovine serum (FBS). Monocytes were then purified by adherence $\left(60 \mathrm{~min}, 37^{\circ} \mathrm{C}\right)$ to the surface of plastic petri dishes coated with defibrinized autologous serum and removed with ethylenediamine tetraacetic acid (EDTA) (0.01 M) in RPMI 1640, 10\% FBS. This was effective in enriching the cell population to greater than $90 \%$ monocytes, with a viability greater than $98 \%$ as assessed by Wright-Giemsa staining and trypan blue exclusion, respectively. Cells were resuspended in RPMI 1640, 10\% FBS, at a final concentration of $2 \times 10^{6}$ cells $/ \mathrm{ml}$. Monocytes were left to rest overnight in polypropylene tubes to allow them to return to baseline status following initial activation by adherence. The medium was then removed by pipetting and replaced by fresh RPMI 1640 without FBS $1 \mathrm{~h}$ before stimulation with hydrogen peroxide. The $30 \% \mathrm{H}_{2} \mathrm{O}_{2}$ stock was diluted in RPMI immediately before treatment. Cell viability after treatment was measured by trypan blue exclusion.

\section{mRNA studies}

After appropriate treatment, cells were pelleted in 15 $\mathrm{ml}$ polypropylene tubes and the total cellular RNA was isolated by acid guanidium thiocyanatephenol-chloroform extraction according to Chomczynski and Sacchi. ${ }^{37}$ RNA $(10 \mu \mathrm{g})$ was separated by electrophoresis on 1\% agarose and transferred onto a Hybond-N (Amersham, Arlington Heights, IL, USA) membrane for northern analysis. The cDNA corre- sponding to the whole coding sequence of human CCR5 was obtained as previously described ${ }^{38}$ from genomic DNA of Raji cells using the primers 5'GCTCTAGAGATTATCAAGTGTC-3' (sense), and 5'GGGGTACCTCACAAGCCCACAGATATTTCCTGCTCCCC-3' (antisense). The c-fos cDNA probe was obtained from the American Type Culture Collection (Rockville, MD, USA). Control hybridizations were performed with the human glyceraldehyde-3-phosphate dehydrogenase (GAPDH) cDNA probe obtained from the American Type Culture Collection. The probes were labelled with a multiprime DNA labeling system (Amersham) using $\left[{ }^{32} \mathrm{P}\right] \mathrm{dCTP}$ (specific activity $>3000 \mathrm{Ci} / \mathrm{mmol}$; Amersham). Membranes were prehybridized for $4 \mathrm{~h}$ in a mixture containing $120 \mathrm{mM}$ of Tris, $600 \mathrm{mM}$ of $\mathrm{NaCl}, 8 \mathrm{mM}$ of EDTA, $0.1 \%$ sodium pyrophosphate, $0.2 \%$ sodium dodecyl sulphate, and $100 \mu \mathrm{g} / \mathrm{ml}$ of heparin. Hybridization was performed overnight at $68^{\circ} \mathrm{C}$ in the same mixture in which the concentration of heparin was increased to $625 \mu \mathrm{g} / \mathrm{ml}$ and dextran sulfate at $10 \%$ was added. The membranes were then washed once at room temperature for $20 \mathrm{~min}$ in $2 \times$ SSC $(1 \times$ SSC: $0.15 \mathrm{M}$ of $\mathrm{NaCl}, 0.15 \mathrm{M}$ of sodium citrate, $\mathrm{pH} 7$ ); once with $0.1 \mathrm{x}$ SSC, $0.1 \%$ sodium dodecyl sulphate at $68^{\circ} \mathrm{C}$ for 60 $\mathrm{min}$, and then rinsed at room temperature with $0.1 \times$ SSC. The membranes were exposed to Kodak XAR-5 film (Eastman Kodak, Rochester, NY, USA) with intensifying screens for $24 \mathrm{~h}$ at $-80^{\circ} \mathrm{C}$. Signal intensity was quantitated by densitometry using a UMAX PowerLook II scanner with the UMAX Magic Scan DA3.1 software and analysed with the NIH Image 1.61 software (Bethesda, MD, USA) on a Macintosh 7300/200 computer. Densitometric values are expressed as ratios of receptor/GAPDH or receptor/28s RNA densitometry quantification and normalized for control $=1$.

\section{Flow cytometry}

The expression of CCR5 on the surface of monocytes was assessed with the monoclonal anti-CCR5 antibody (2D7) (PharMingen, Mississauga, Ontario, Canada) and anti-IgG2a antibody (PharMingen) at 2.5 $\mu \mathrm{g} / \mathrm{ml}$, as previously described. ${ }^{38}$ In brief, $3 \times 10^{5}$ treated cells were washed twice with PBS and labelled for $30 \mathrm{~min}$ at $4^{\circ} \mathrm{C}$ with anti-CCR5, washed with cold PBS and incubated for $30 \mathrm{~min}$ at $4^{\circ} \mathrm{C}$ with FITC-conjugated goat anti-mouse IgG (Bio/Can Scientific, Mississauga, Ontario, Canada). Finally, cells were washed and resuspended in PBS before flow cytometry analysis with a FACScan flow cytometer (Becton-Dickinson, San Jose, CA, USA). Results are expressed as the mean peak channel fluorescence for each treatment. 


\section{Chemotaxis assay}

Monocyte chemotactic activity was performed in modified single-well Boyden chambers separated by $5 \mu \mathrm{m}$ pore size polycarbonate filters (Neuroprobe, Cabin John, MD, USA), as previously described. ${ }^{38}$ MIP- $1 \beta$ or medium was added to the lower chamber and $200 \mu \mathrm{l}$ of monocytes $\left(6 \times 10^{5}\right)$ in Gey's BSS (Gibco-BRL, Burlington, ON, Canada), supplemented with $2 \%$ bovine serum albumin, were added to the upper chamber. In chemokinesis assays, both chambers contained an equal concentration of MIP-1 $\beta$. After incubation for $2 \mathrm{~h}$ at $37^{\circ} \mathrm{C}$, the filters were disassembled and the upper side of the filters were scraped free of cells. Cells on the lower side were removed with $5 \mathrm{mM}$ of EDTA, centrifuged and counted.

\section{Statistical analysis}

Data were analysed for statistical significance using analysis of variance or Student's $t$-test for paired values, as appropriate. Differences were considered significant at $p<0.05$. Results are expressed, when relevant, as means \pm SEM.

A

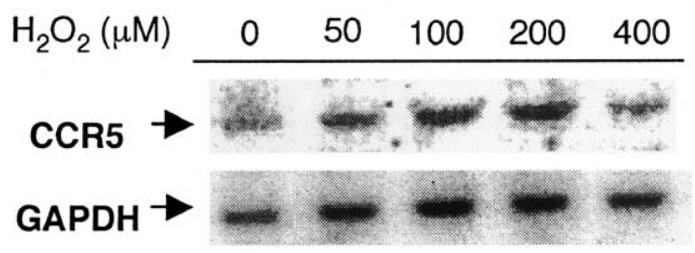

B

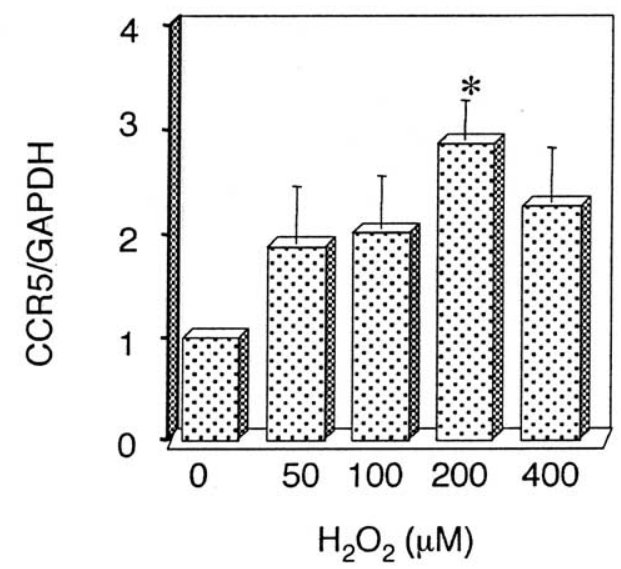

FIG. 1. Induction of CCR5 mRNA expression by $\mathrm{H}_{2} \mathrm{O}_{2}$ in human monocytes. Human monocytes were incubated for 4 h with graded concentrations of $\mathrm{H}_{2} \mathrm{O}_{2}$ in serum-free RPMI 1640 medium and total RNA was extracted and analysed by northern blotting for CCR5 mRNA expression. (A) Autoradiogram of one representative experiment. (B) Densitometric quantification of CCR5 mRNA normalized to GAPDH mRNA. The results represent the means \pm SEM of nine independent experiments. ${ }^{*} p<0.05, \mathrm{H}_{2} \mathrm{O}_{2}$-treated versus control cells.

\section{Results}

Monocytes isolated from different blood donors were treated with graded concentrations of $\mathrm{H}_{2} \mathrm{O}_{2}$ for $4 \mathrm{~h}$ and mRNA levels encoding CCR5 were measured by northern blot analysis. As illustrated in Fig. 1, $\mathrm{H}_{2} \mathrm{O}_{2}$ induced a concentration-dependent augmentation of CCR 5 mRNA expression in human monocytes with a maximum induction at $200 \mu \mathrm{M}$ of $\mathrm{H}_{2} \mathrm{O}_{2}$. Parallel experiments were performed to evaluate the effect of $\mathrm{H}_{2} \mathrm{O}_{2}$ on the expression of the chemokine receptor CXCR4 and the receptor for the lipid mediator, platelet-activating factor (PAFR). As illustrated in Fig. 2A, $\mathrm{H}_{2} \mathrm{O}_{2}$ also induced an increase in CXCR 4 mRNA expression, albeit of a lesser magnitude, but had no effect on PAFR mRNA expression (Fig. 2B). In a time-course study, illustrated in Fig. 3, the effect of $\mathrm{H}_{2} \mathrm{O}_{2}$ on CCR5 mRNA levels was detectable as early as at $2 \mathrm{~h}$ of treatment, was maximal by $4 \mathrm{~h}$ and decreased by $24 \mathrm{~h}$.

Increased mRNA expression is commonly controlled by a transcriptional or post-transcriptional mechanism. To determine whether $\mathrm{H}_{2} \mathrm{O}_{2}$ elevated CCR5 mRNA levels through transcriptional activation, monocytes were pretreated with Actinomycin D, a transcriptional inhibitor, for $15 \mathrm{~min}$. The cells were then treated with medium or $200 \mu \mathrm{M}$ of $\mathrm{H}_{2} \mathrm{O}_{2}$ for $3 \mathrm{~h}$. Total cellular RNA was then extracted and northern blot analysis was performed. As illustrated in Fig. 4, this treatment blocked the $\mathrm{H}_{2} \mathrm{O}_{2}$-induced accumulation of CCR5 mRNA, suggesting that $\mathrm{H}_{2} \mathrm{O}_{2}$-regulated CCR5 expression involves a transcriptional mechanism.

Since the transcription factor $\mathrm{NF}-\kappa \mathrm{B}$ has been shown to be affected by $\mathrm{H}_{2} \mathrm{O}_{2}$ in some cell lines and in $\mathrm{T}$ lymphocytes, ${ }^{29,39}$ and because the CCR5 gene promoter contains consensus binding sequences for this transcription factor, ${ }^{36}$ we examined

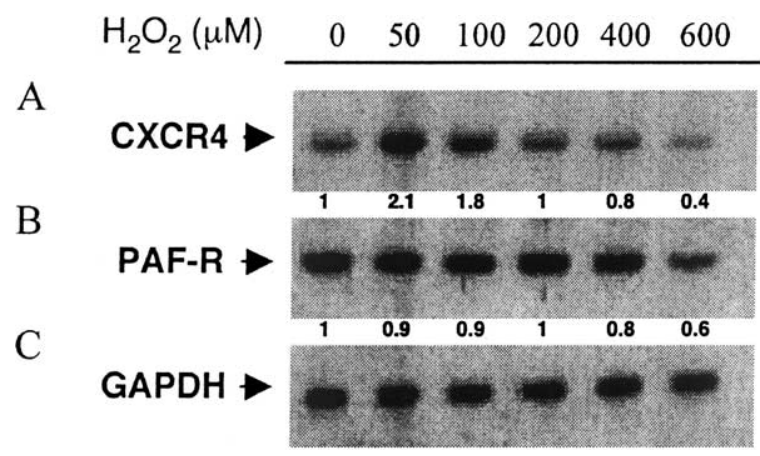

FIG. 2. Effect of $\mathrm{H}_{2} \mathrm{O}_{2}$ on the expression of CXCR4 and PAFR mRNA in human monocytes. Human monocytes were incubated for $4 \mathrm{~h}$ with graded concentrations of $\mathrm{H}_{2} \mathrm{O}_{2}$ in serum-free RPMI 1640 medium and total RNA was extracted and analysed by northern blotting for CXCR4 and PAFR mRNA expression. (A) Autoradiogram of northern blot hybridized with radiolabelled CXCR4 cDNA. The same membrane was rehybridized with radiolabelled PAFR (B) or GAPDH (C) cDNA. 


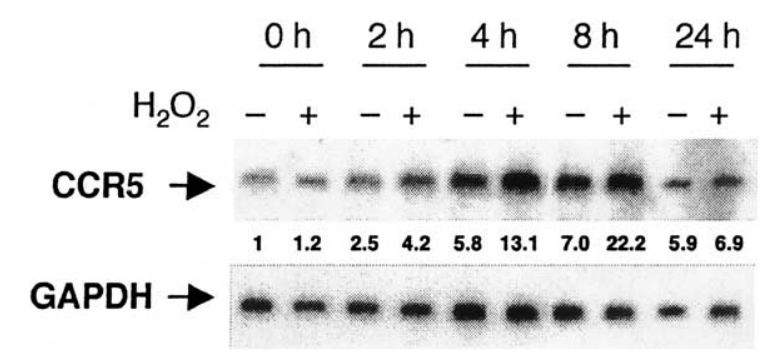

FIG. 3. Time course of $\mathrm{H}_{2} \mathrm{O}_{2}$-induced upregulation of CCR5 gene expression. Monocytes were incubated in the absence or presence of $\mathrm{H}_{2} \mathrm{O}_{2}(200 \mu \mathrm{M})$ for the indicated time periods followed by northern blot analysis of CCR5 gene expression. Total RNA was then extracted and analysed by northern blot for CCR5 and GAPDH gene expression. The results are representative of two independent experiments.

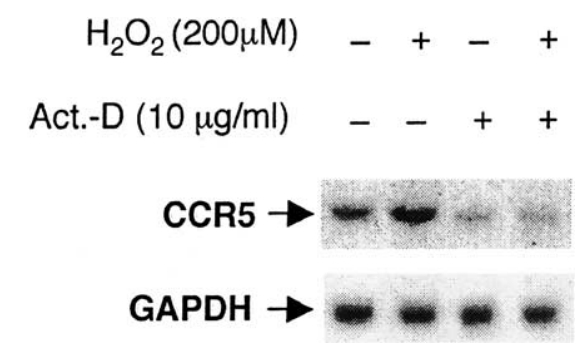

FIG. 4. Effect of Actinomycin D (Act-D) on CCR5 mRNA expression in response to $\mathrm{H}_{2} \mathrm{O}_{2}$. Monocytes were incubated in the absence or presence of Actinomycin $D(10 \mu \mathrm{g} / \mathrm{ml})$ for 15 min before addition of either medium or $\mathrm{H}_{2} \mathrm{O}_{2}$ for $3 \mathrm{~h}$. Total RNA was then extracted and analysed by northern blot for CCR5 and GAPDH gene expression. The results are representative of two independent experiments.

the effect of an inhibitor of NF- $\kappa \mathrm{B}$ on $\mathrm{H}_{2} \mathrm{O}_{2}$-induced expression of CCR5 mRNA. As shown in Fig. 5, CCR5 mRNA induction by $\mathrm{H}_{2} \mathrm{O}_{2}$ was largely inhibited following pretreatment with $20 \mu \mathrm{M}$ of BAY 11-7082, an inhibitor of $I \kappa B-\alpha$ phosphorylation. Thus, the stimulatory effects of $\mathrm{H}_{2} \mathrm{O}_{2}$ on CCR5 expression appears to be mediated, at least in part, through the activation of the $\mathrm{NF}-\kappa \mathrm{B}$ signalling pathway.

We then investigated whether $\mathrm{H}_{2} \mathrm{O}_{2}$-induced accumulation of CCR 5 mRNA was associated with an increased expression of CCR5 protein on the cell

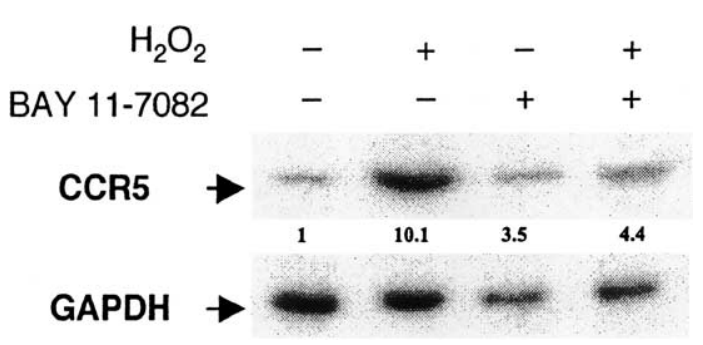

FIG. 5. Effect of BAY 11-7082 pretreatment on $\mathrm{H}_{2} \mathrm{O}_{2}$-induced CCR5 mRNA expression. Monocytes were incubated in the absence or presence of Bay 11-7082 (20 $\mu \mathrm{M})$ for $30 \mathrm{~min}$ before addition of either medium or $\mathrm{H}_{2} \mathrm{O}_{2}(200 \mu \mathrm{M})$. Total RNA was extracted and analysed by northern blot for the expression of CCR5 and GAPDH mRNA. The results are representative of three independent experiments. surface. Monocytes were treated for $4 \mathrm{~h}$ with either medium or $200 \mu \mathrm{M} \mathrm{H}_{2} \mathrm{O}_{2}$. Supernatants were then replaced with new medium and cells were incubated for $16 \mathrm{~h}$. Flow cytometry studies were then performed using the 2D7 monoclonal anti-CCR5 antibody. As illustrated in Fig. 6, $\mathrm{H}_{2} \mathrm{O}_{2}$ treatment of monocytes induced a marked increase in membrane expression of CCR5, as compared with untreated cells $\left(\mathrm{H}_{2} \mathrm{O}_{2}\right.$-treated monocytes, $6.11 \pm 1.7$ peak channel fluorescence versus control cells, 2.44 $\pm 0.6 ; p<$ $0.05)$.

To assess the specificity of action of $\mathrm{H}_{2} \mathrm{O}_{2}$, monocytes were treated with $\mathrm{H}_{2} \mathrm{O}_{2}$ in the presence or absence of catalase, which degrades $\mathrm{H}_{2} \mathrm{O}_{2}$ to $\mathrm{H}_{2} \mathrm{O}$ and $\mathrm{O}_{2}$. As expected, the $\mathrm{H}_{2} \mathrm{O}_{2}$-induced upregulation of CCR5 expression was prevented by catalase both at the mRNA and protein levels (Fig. 7A,B). Interestingly, however, catalase itself was found to increase the expression of CCR5.

We next investigated whether the $\mathrm{H}_{2} \mathrm{O}_{2}$-induced upregulation of CCR5 expression was associated with augmented responsiveness of treated monocytes to the CCR5 ligand MIP-1 $\beta$. Receptor function was first evaluated for MIP-1 $\beta$-induced chemotaxis; as shown in Fig. 8, monocytes pretreated with $\mathrm{H}_{2} \mathrm{O}_{2}$ showed enhanced responsiveness to the chemotactic action of MIP-1 $\beta$. Chemokinetic activity in response to MIP$1 \beta$ was not affected, however (data not shown). CCR5 function was also evaluated in terms of MIP-1 $\beta$ induced c-fos expression. After a $4 \mathrm{~h}$ pretreatment with $200 \mu \mathrm{M}$ of $\mathrm{H}_{2} \mathrm{O}_{2}$, followed by an incubation of $16 \mathrm{~h}$ in new medium, cells were treated for $30 \mathrm{~min}$ with 50 or $100 \mathrm{ng} / \mathrm{ml}$ of MIP-1 $\beta$ and the total RNA was

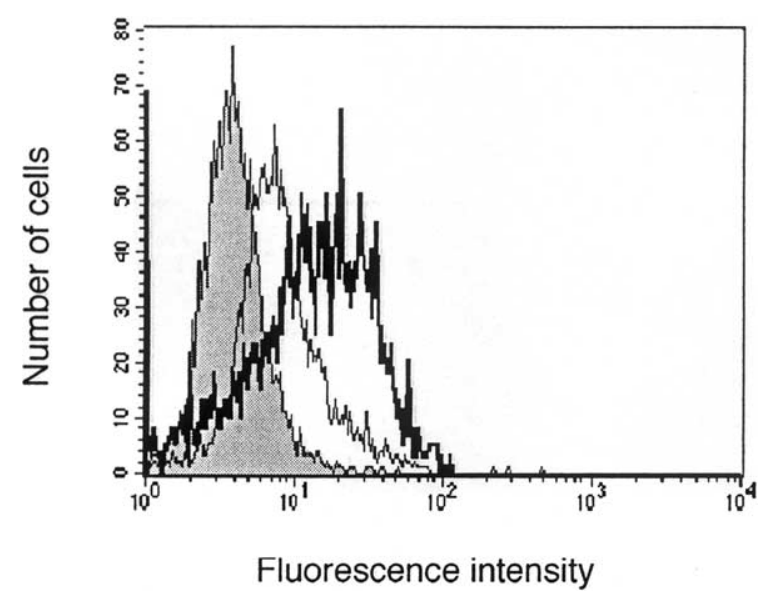

FIG. 6. Effect of $\mathrm{H}_{2} \mathrm{O}_{2}$ on CCR5 protein expression. Monocytes were treated with $200 \mu \mathrm{M}$ of $\mathrm{H}_{2} \mathrm{O}_{2}$ for $4 \mathrm{~h}$ in serum-free medium and centrifuged for $5 \mathrm{~min}$ at $1000 \mathrm{rpm}$. The medium was then replaced by new medium and the cells were incubated for $16 \mathrm{~h}$. The medium was then removed by aspiration without centrifugation. Cells were labelled with either an irrelevant antibody (shaded) or anti-CCR-5 (2D7) antibody, followed by FITC-conjugated goat anti-mouse antibody. Cells were analysed by flow cytometry (untreated cells, thin line; $\mathrm{H}_{2} \mathrm{O}_{2}$-treated cells, thick line). A representative experiment of nine independent experiments is illustrated. 


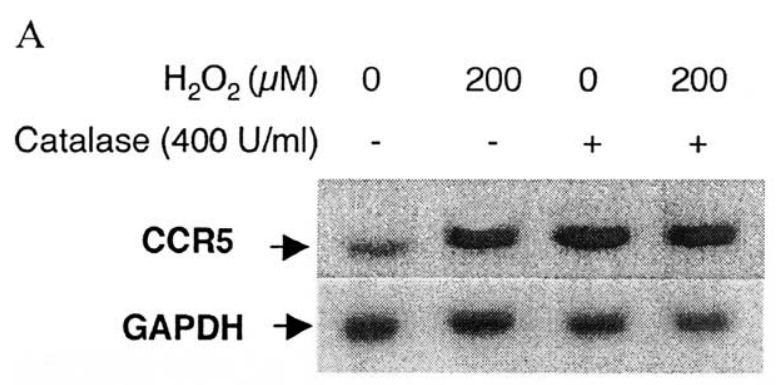

B

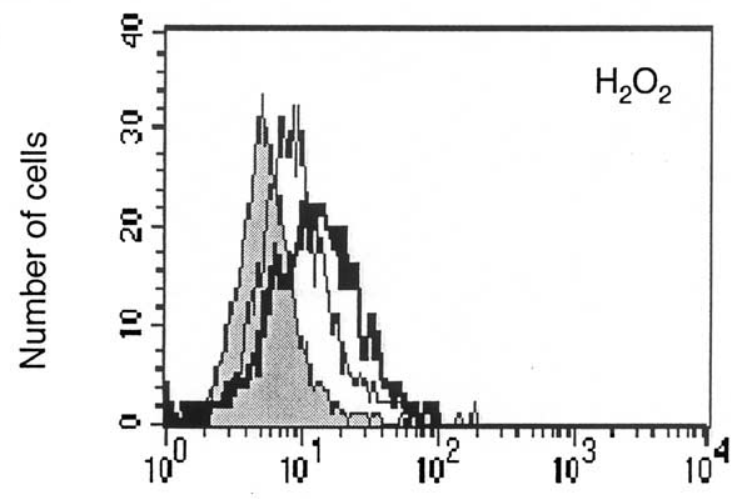

Fluorescence intensity

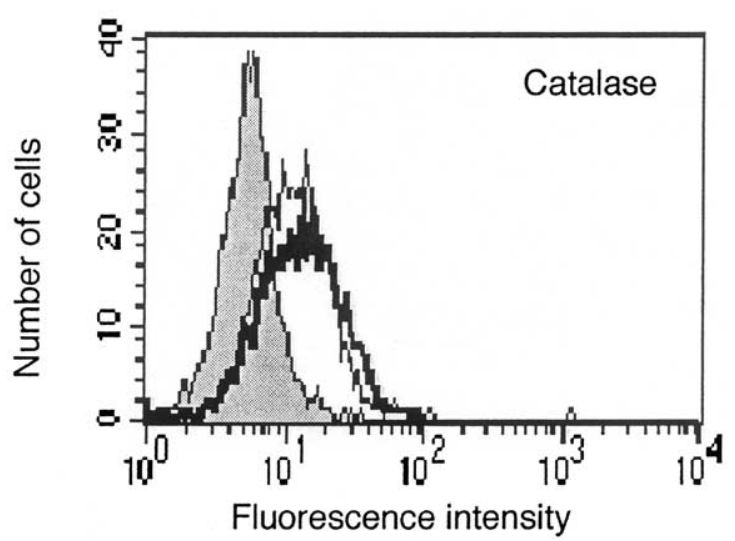

FIG. 7. Effect of catalase on CCR5 expression. (A) Monocytes were treated with $200 \mu \mathrm{M}$ of $\mathrm{H}_{2} \mathrm{O}_{2}$ in the absence or presence of catalase $(400 \mathrm{U} / \mathrm{ml})$ for $4 \mathrm{~h}$ in serum-free medium and total RNA was extracted and analysed by northern blotting for CCR5 mRNA expression. Autoradiogram of one representative experiment. (B) Monocytes were treated with $200 \mu \mathrm{M}$ of $\mathrm{H}_{2} \mathrm{O}_{2}$ in the absence or presence of catalase $(400 \mathrm{U} / \mathrm{ml})$ for $4 \mathrm{~h}$ in serum-free medium. The medium was then replaced following centrifugation by new medium and the cells were incubated for $16 \mathrm{~h}$ at $37^{\circ} \mathrm{C}$. The medium was then removed by aspiration without centrifugation. Cells were labelled with either an irrelevant antibody (shaded) or anti-CCR-5 (2D7) antibody, followed by FITC-conjugated goat anti-mouse antibody. Cells were analysed by flow cytometry (untreated cells, thin line; $\mathrm{H}_{2} \mathrm{O}_{2}$-treated cells, thick line).

extracted for northern blot analysis. As illustrated in Fig. 9, c-fos mRNA expression was markedly increased in $\mathrm{H}_{2} \mathrm{O}_{2}$-pretreated monocytes following exposure with MIP-1 $\beta$, compared with untreated cells. These observations suggest that the increased expression of CCR5 following $\mathrm{H}_{2} \mathrm{O}_{2}$ treatment is associated with enhanced functional activities of the receptor.

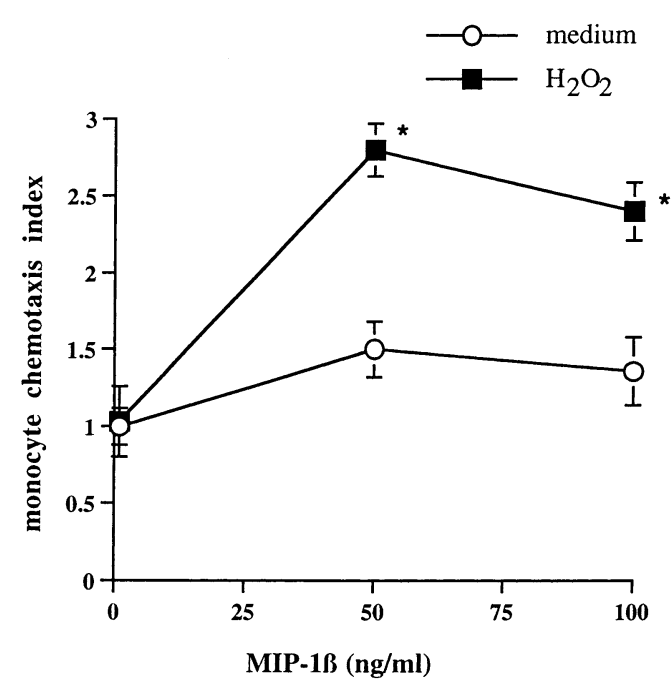

FIG. 8. Effect of $\mathrm{H}_{2} \mathrm{O}_{2}$ on monocyte chemotaxis. Monocytes were treated with either medium or $200 \mu \mathrm{M}$ of $\mathrm{H}_{2} \mathrm{O}_{2}$ for $4 \mathrm{~h}$ in serum-free medium. The medium was then replaced by new medium and the cells were incubated for $16 \mathrm{~h}$ at $37^{\circ} \mathrm{C}$. Chemotactic activity was measured in response to MIP-1 $\beta$ using a modified Boyden chamber chemotaxis assay. The figure illustrates the means \pm SEM of triplicate determinations of one representative experiment.

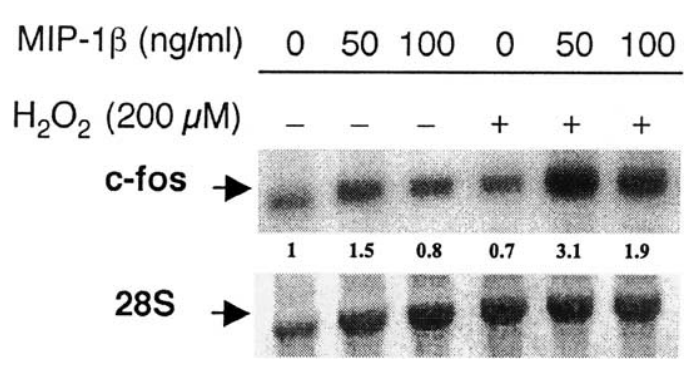

FIG. 9. Effect of $\mathrm{H}_{2} \mathrm{O}_{2}$ on MIP-1 $\beta$-induced c-fos expression. Monocytes were treated with either medium or $200 \mu \mathrm{M}$ of $\mathrm{H}_{2} \mathrm{O}_{2}$ for $4 \mathrm{~h}$ in serum-free medium. The medium was then replaced by new medium and the cells were incubated for 16 $h$ at $37^{\circ} \mathrm{C}$. MIP- $1 \beta$ or medium were then added for $20 \mathrm{~min}$ and total RNA was extracted for northern blot analysis. The autoradiogram of one experiment representative of two independent experiments is shown.

\section{Discussion}

It is now accepted that a wide variety of cell types can respond to oxidative stress by the induction of multiples genes controlled by redox-sensitive proteins. ${ }^{40}$ Several investigators have demonstrated that ROS can modulate gene expression of chemokines such as IL- $8,{ }^{41}$ MCP- $1^{21,42}$ and MIP- $1 \alpha,{ }^{22}$ suggesting a role for ROS in the inflammation process. In this report, we demonstrated that externally applied $\mathrm{H}_{2} \mathrm{O}_{2}$, a cell-permeable oxidant, significantly increased mRNA expression of the chemokine receptors CCR5 and, to a lesser extent, CXCR4 in human monocytes. Similar findings were recently reported by Saccani et al., ${ }^{43}$ who also found that the antioxidant pyrrolidinedithiocarbamate (PDTC) downregulated the expression of CCR5 and CXCR4. 
We further extended our studies by showing that the upregulation of CCR5 by $\mathrm{H}_{2} \mathrm{O}_{2}$ was dependent on transcriptional activity and could be prevented by inhibition of NF- $\kappa B$ activation. Moreover, the $\mathrm{H}_{2} \mathrm{O}_{2}-$ induced augmentation of CCR5 mRNA levels was associated with enhanced CCR5 expression at the cell surface. We further demonstrated that these newly induced receptors were functional since pretreatment with $\mathrm{H}_{2} \mathrm{O}_{2}$ was associated with an augmented responsiveness of monocytes to MIP-1 $\beta$ in terms of cell migration as well as c-fos gene activation.

The transcription factor $N F-\kappa B$ is involved in the expression of a wide variety of genes controlling immune and inflammatory responses. Several lines of evidence suggest a role for ROS as a common and critical intermediate in NF- $\kappa \mathrm{B}$ activating signals. For example, the antioxidant PDTC or the overexpression of superoxide dismutase have been shown to be inhibitory for TNF-induced activation of NF- $\kappa \mathrm{B}$ in Jurkat $\mathrm{T}$ cells. ${ }^{27,44-47}$ It has also been shown that addition of $\mathrm{H}_{2} \mathrm{O}_{2}$ to specific cell types results in the appearance of the phosphorylated form of $\mathrm{I} \kappa \mathrm{B}-\alpha$, whereas treatment with reducing agents such as dithiothreitol and $\beta$-mercaptoethanol enhances DNA-binding activity of NF- $\kappa \mathrm{B}$ itself. ${ }^{48}$ Consistant with these reports, treatment with antioxidants or overexpression of antioxidant enzymes can block I $\mathrm{B}-\alpha$ phosphorylation and degradation induced by lipopolysaccharide, TNF- $\alpha$ and phorbol-myristate acetate (PMA). ${ }^{35}$ These observations suggest that redox regulation may affect more than one step in the NF- $\kappa \mathrm{B}$ activating pathway. Although the molecular mechanism of the redox regulation of $\mathrm{NF}-\kappa \mathrm{B}$ is still unclear, signalling molecules such as protein kinases, which are involved in the dissociation of IкB from the NF- $\kappa \mathrm{B}$ complex, may be targets of the redox regulation. Our study also suggests a role for the NF$\kappa \mathrm{B}$ pathway in the effect mediated by $\mathrm{H}_{2} \mathrm{O}_{2}$ on CCR5 expression in monocytes. Since the preatreatment of cells with an I $\kappa \mathrm{B}-\alpha$ phosphorylation inhibitor resulted in a partial inhibition of the $\mathrm{H}_{2} \mathrm{O}_{2}$-mediated induction of CCR 5 mRNA, we can suppose that I $\kappa \mathrm{B}-\alpha$ itself or some upstream factors, such as one or more protein kinases, could be the target for the oxidant. Moreover, the CCR5 gene promoter also contains consensus binding sequences for the transcriptional activating factor AP-1 and for such regulatory elements as STAT, ${ }^{36}$ which have recently been shown to be redox sensitive. ${ }^{30}$ These findings present the possibility that additional transcription factors might be implicated in the regulation of CCR5 expression by $\mathrm{H}_{2} \mathrm{O}_{2}$.

Regulation of chemokine receptors by reactive oxygen species may be important in the pathogenesis of several inflammatory diseases. ROS have been shown to be produced by immune cells after activation by proinflammatory cytokines, such as IL-1 and TNF- $\alpha .{ }^{49}$ ROS are also implicated in a number of inflammatory diseases where expression of CCR5 ligands is enhanced, such as in rheumatoid arthritis, sepsis and autoimmune encephalomyelitis. ${ }^{50-53}$ Understanding the effect of ROS in the direct environment of inflammatory cells could lead to a better understanding of the mechanisms implicated in the progression of these diseases.

In conclusion, our results demonstrate that ROS in the extracellular environment of human monocytes can increase the expression of the chemokine receptor CCR5 through redox-sensitive transcription factors, such as NF- $\kappa$ B. In an inflammatory disease context, activated phagocytic cells would release inflammatory mediators and ROS, such as $\mathrm{H}_{2} \mathrm{O}_{2}$. $\mathrm{H}_{2} \mathrm{O}_{2}$ accumulation in the environment of immune cells would then promote an increase in CCR5 expression on the cell surface of monocytes, leading to a greater response to the chemokines MIP- $1 \alpha$, MIP$1 \beta$ and RANTES. This increased response to chemokines would extend the inflammatory process and possibly facilitate a greater accumulation of activated monocytes at the inflammatory site.

ACKNOWLEDGEMENTS. The authors wish to thank Sylvie Turcotte, Maryse Thivierge and Denis Gingras for excellent technical assistance.

\section{References}

1. Raport CJ, Schweickart VL, Chantry D, Eddy Jr RL, Shows TB, Godiska R, Gray PW. New members of the chemokine receptor gene family. $J$ Leukoc Biol 1996; 59: 18-23.

2. Raport CJ, Gosling J, Schweickart VL, Gray PW, Charo IF. Molecular cloning and functional characterization of a novel human CC chemokine receptor (CCR5) for RANTES, MIP-1beta, and MIP-1alpha. J Biol Chem 1996; 271: $17161-17166$.

3. Samson M, Labbe O, Mollereau C, Vassart G, Parmentier M. Molecular cloning and functional expression of a new human CC-chemokine receptor gene. Biochemistry 1996; 35: 3362-3367.

4. Hall IP, Wheatley A, Christie G, McDougall C, Hubbard R, Helms PJ. Association of CCR5 delta32 with reduced risk of asthma [letter]. Lancet 1999; 354: 1264-1265.

5. Panzer U, Schneider A, Wilken J, Thompson DA, Kent SB, Stahl RA. The chemokine receptor antagonist AOP-RANTES reduces monocyte infiltration in experimental glomerulonephritis. Kidney Int 1999; 56: $2107-$ 2115.

6. Topham PS, Csizmadia V, Soler D, Hines D, Gerard CJ, Salant DJ Hancock WW Lack of chemokine receptor CCR1 enhances Th1 responses and glomerular injury during nephrotoxic nephritis. J Clin Invest 1999; 104: 1549-1557.

7. Wada T, Furuichi K, Segawa-Takaeda C, et al. MIP-1alpha and MCP-1 contribute to crescents and interstitial lesions in human crescentic glomerulonephritis. Kidney Int 1999; 56: 995-1003.

8. Babior BM, Kipnes RS, Curnutte JT. Biological defense mechanisms. The production by leukocytes of superoxide, a potential bactericidal agent. $J$ Clin Invest 1973; 52: 741-744.

9. Sbarra AJ, Paul BB, Jacobs AA, Strauss RR, Mitchell Jr. GW. Biochemical aspects of phagocytic cells as related to bactericidal function. $J$ Reticuloendothel Soc 1972; 11: 492-502.

10. Baehner RL, Nathan DG, Castle WB. Oxidant injury of caucasian glucose-6-phosphate dehydrogenase-deficient red blood cells by phagocytosing leukocytes during infection. J Clin Invest 1971; 50: $2466-$ 2473 .

11. Bell AL, Markey GM, Alexander HD, Morris TC, McMillan SA, McNally JA. Myeloperoxidase deficiency in a patient with rheumatoid arthritis: oxygenation and radical activity by phagocytic cells. Br J Rheumatol 1993; 32: $162-165$

12. Vachier I, Damon M, Le Doucen C, de Paulet AC, Chanez P, Michel FB, Godard P. Increased oxygen species generation in blood monocytes of asthmatic patients. Am Rev Respir Dis 1992; 146: 1161-1166.

13. Bandres JC, Trial J, Musher DM, Rossen RD. Increased phagocytosis and generation of reactive oxygen products by neutrophils and monocytes 
of men with stage 1 human immunodeficiency virus infection. J Infect Dis 1993; 168: $75-83$.

14. Chapple IL. Reactive oxygen species and antioxidants in inflammatory diseases. J Clin Periodontol 1997; 24: 287-296.

15. Buttke TM, Sandstrom PA. Oxidative stress as a mediator of apoptosis [see comments]. Immunol Today 1994; 15: 7-10.

16. Baeuerle PA, Baltimore D. NF-kappa B: ten years after. Cell 1996; 87 $13-20$.

17. Baeuerle PA, Rupec RA, Pahl HL. Reactive oxygen intermediates as second messengers of a general pathogen response. Pathol Biol 1996; 44: $29-35$.

18. Finkel T. Oxygen radicals and signaling. Curr Opin Cell Biol 1998; 10 $248-253$.

19. Finkel T. Signal transduction by reactive oxygen species in nonphagocytic cells. J Leukoc Biol 1999; 65: 337-340.

20. Verhasselt V, Goldman M, Willems F. Oxidative stress up-regulates IL-8 and TNF-alpha synthesis by human dendritic cells. Eur J Immunol 1998 28: $3886-3890$.

21. Lee JS, Kahlon SS, Culbreth R, Cooper Jr. AD. Modulation of monocyte chemokine production and nuclear factor kappa B activity by oxidants. $J$ Interferon Cytokine Res 1999; 19: 761-767.

22. Shi MM, Godleski JJ, Paulauskis JD. Regulation of macrophage inflammatory protein-1alpha mRNA by oxidative stress. J Biol Chem 1996; 271: 5878-5883

23. Los M, Schenk H, Hexel K, Baeuerle PA, Droge W, Schulze-Osthoff K. IL2 gene expression and NF-kappa B activation through $\mathrm{CD} 28$ requires reactive oxygen production by 5-lipoxygenase. EMBOJ 1995; 14: 3731 3740 .

24. Schulze-Osthoff K, Los M, Baeuerle PA. Redox signalling by transcription factors NF-kappa B and AP-1 in lymphocytes. Biochem Pharmacol 1995; 50: $735-741$

25. Baeuerle PA. IkappaB-NF-kappaB structures: at the interface of inflammation control. Cell 1998; 95: 729-731.

26. Meyer M, Pahl HL, Baeuerle PA. Regulation of the transcription factors NF-kappa B and AP-1 by redox changes. Chem Biol Interact 1994; 91 $91-100$.

27. Meyer M, Schreck R, Baeuerle PA. $\mathrm{H}_{2} \mathrm{O}_{2}$ and antioxidants have opposite effects on activation of NF-kappa B and AP-1 in intact cells: AP-1 as secondary antioxidant-responsive factor. EMBO J 1993; 12: 2005-2015.

28. Devary Y, Gottlieb RA, Lau LF, Karin M. Rapid and preferential activation of the c-jun gene during the mammalian UV response. Mol Cell Biol 1991; 11: $2804-2811$.

29. Schreck R, Albermann K, Baeuerle PA. Nuclear factor kappa B: an oxidative stress-responsive transcription factor of eukaryotic cells (a review). Free Radic Res Commun 1992; 17: 221-237.

30. Kamata H, Hirata H. Redox regulation of cellular signalling. Cell Signal 1999; 11: $1-14$.

31. Siebenlist U, Franzoso G, Brown K. Structure, regulation and function of NF-kappa B. Annu Rev Cell Biol 1994; 55: 405-455.

32. Baldwin Jr. AS. The NF-kappa B and I kappa B proteins: new discoveries and insights. Annu Rev Immunol 1996; 14: 649-683.

33. Barnes PJ, Karin M. Nuclear factor-kappaB: a pivotal transcription factor in chronic inflammatory diseases. N Engl J Med 1997; 336: 1066-1071.

34. Brown K, Gerstberger S, Carlson L, Franzoso G, Siebenlist U. Control of kappa B-alpha proteolysis by site-specific, signal-induced phosphorylation. Science 1995; 267: 1485-1488.

35. Traenckner EB, Wilk S, Baeuerle PA. A proteasome inhibitor prevents activation of NF-kappa B and stabilizes a newly phosphorylated form of I kappa B-alpha that is still bound to NF-kappa B. EMBO J 1994; 13 $5433-5441$.

36. Liu R, Zhao X, Gurney TA, Landau NR. Functional analysis of the proximal CCR5 promoter. AIDS Res Hum Retroviruses 1998; 14: 15091519 .

37. Chomczynski P, Sacchi N. Single-step method of RNA isolation by acid guanidinium thiocyanate-phenol-chloroform extraction. Anal Biochem 1987; 162: 156-159.
38. Thivierge M, Le Gouill C, Stankova J, Rola-Pleszczynski M. Prostaglandin $\mathrm{E}_{2}$ induces resistance to HIV-1 infection in monocyte-derived macrophages: down-regulation of CCR5 expression by Camp. Blood 1998; 92 $40-45$.

39. Schreck R, Rieber P, Baeuerle PA. Reactive oxygen intermediates as apparently widely used messengers in the activation of the NF-kappa B transcription factor and HIV-1. EMBO J 1991; 10: 2247-2258.

40. Allen JF. Redox control of transcription: sensors, response regulators, activators and repressors. FEBS Lett 1993; 332: 203-207.

41. Roebuck KA. Oxidant stress regulation of IL-8 and ICAM-1 gene expression: differential activation and binding of the transcription factors AP-1 and NF-kappaB. Int J Mol Med 1999; 4: 223-230.

42. Satriano JA, Shuldiner M, Hora K, Xing Y, Shan Z, Schlondorff D Oxygen radicals as second messengers for expression of the monocyte chemoattractant protein, JE/MCP-1, and the monocyte colony-stimulating factor, CSF-1, in response to tumor necrosis factor-alpha and immunoglobulin G. Evidence for involvement of reduced nicotinamide adenine dinucleotide phosphate (NADPH)-dependent oxidase. J Clin Invest 1993; 92: 1564-1571.

43. Saccani A, Saccani S, Orlando S, Sironi M, Bernasconi S, Ghezzi P, Mantovani A, Sica A. Redox regulation of chemokine receptor expression. Proc Natl Acad Sci USA 2000; 97: 2761-2766.

44. Manna SK, Zhang HJ, Yan T, Oberley LW, Aggarwal BB. Overexpression of manganese superoxide dismutase suppresses tumor necrosis factorinduced apoptosis and activation of nuclear transcription factor-kappaB and activated protein-1. J Biol Chem 1998; 273: 13245-13254.

45. Meister A, Anderson ME. Glutathione. Annu Rev Biochem 1983; 52 $711-760$.

46. Aruoma OI, Halliwell B, Hoey BM, Butler J. The antioxidant action of Nacetylcysteine: its reaction with hydrogen peroxide, hydroxyl radical, superoxide, and hypochlorous acid. Free Radic Biol Med 1989; 6: $593-$ 597

47. Kretz-Remy C, Mehlen P, Mirault ME, Arrigo AP. Inhibition of I kappa Balpha phosphorylation and degradation and subsequent NF-kappa B activation by glutathione peroxidase overexpression. J Cell Biol 1996; 133: 1083-1093

48. Mercurio F, Manning AM. NF-kappaB as a primary regulator of the stress response. Oncogene 1999; 18: 6163-6171.

49. Pathania V, Syal N, Pathak CM, Khanduja KL. Vitamin E suppresses the induction of reactive oxygen species release by lipopolysaccharide, interleukin-1beta and tumor necrosis factor-alpha in rat alveolar macrophages. J Nutr Sci Vitaminol 1999; 45: 675-686.

50. Sahnoun Z, Jamoussi K, Zeghal KM. Free radicals and antioxidants: physiology, human pathology and therapeutic aspects (part II). Therapie 1998; 53: 315-339.

51. Karpus WJ, Lukacs NW, McRae BL, Strieter RM, Kunkel SL, Miller SD. An important role for the chemokine macrophage inflammatory protein-1 alpha in the pathogenesis of the T cell-mediated autoimmune disease, experimental autoimmune encephalomyelitis. J Immunol 1995; 155 5003-5010.

52. Kunkel SL, Standiford T, Kasahara K, Strieter RM. Interleukin-8 (IL-8): the major neutrophil chemotactic factor in the lung. Exp Lung Res 1991; 17: $17-23$.

53. Xing Z, Jordana $M$, Braciak T, Ohtoshi T, Gauldie J. Lipopolysaccharide induces expression of granulocyte/macrophage colony-stimulating factor, interleukin-8, and interleukin- 6 in human nasal, but not lung, fibroblasts: evidence for heterogeneity within the respiratory tract. $A m J$ Respir Cell Mol Biol 1993; 9: 255-263.

Received 22 November 2002

Accepted 3 December 2002 


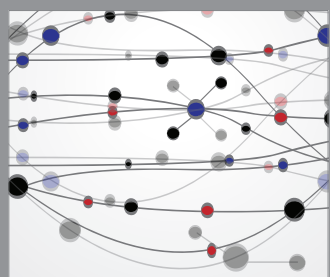

The Scientific World Journal
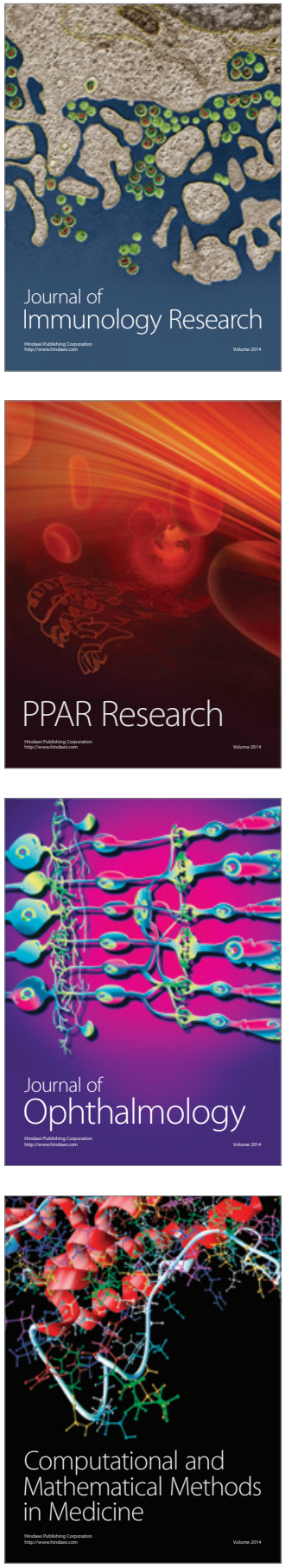

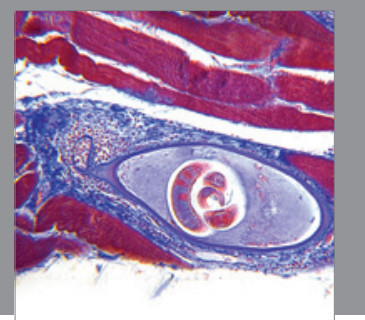

Gastroenterology

Research and Practice
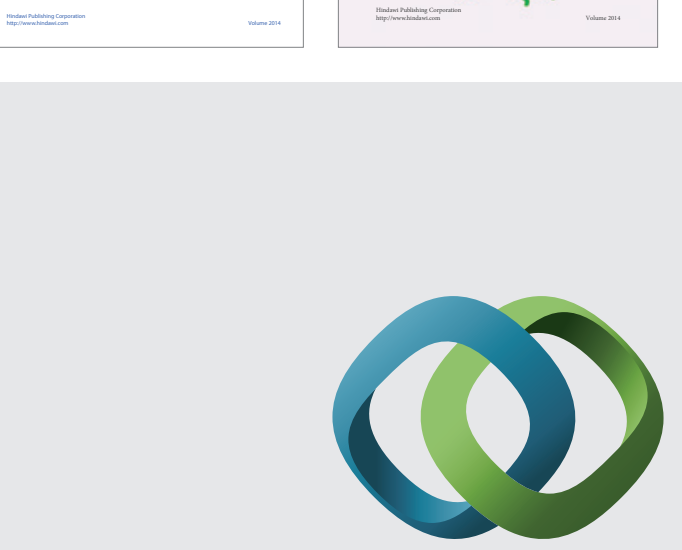

\section{Hindawi}

Submit your manuscripts at

http://www.hindawi.com
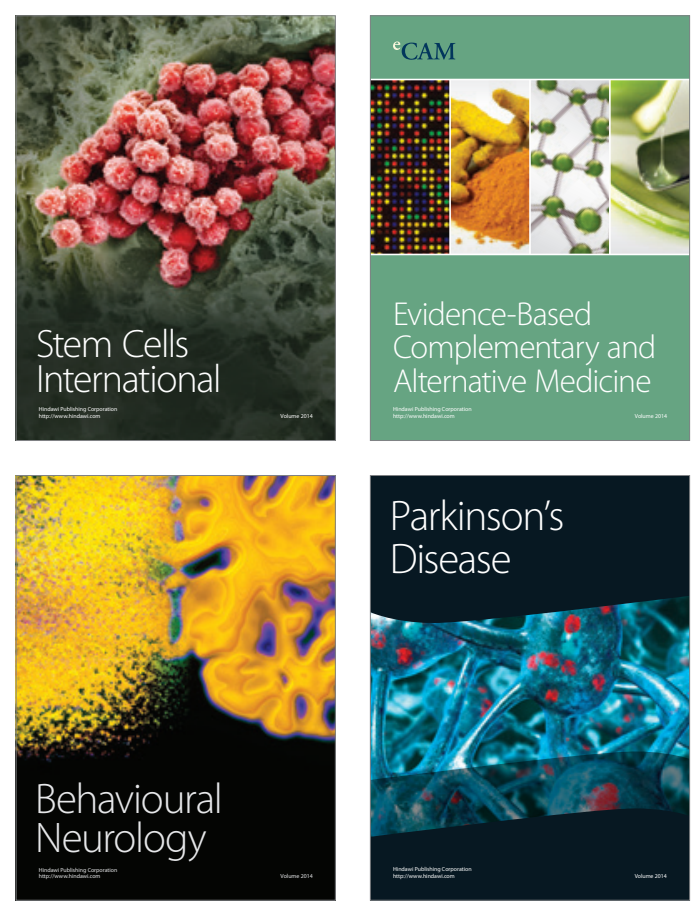

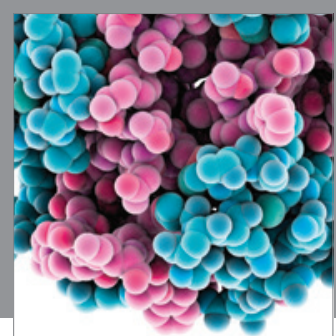

Journal of
Diabetes Research

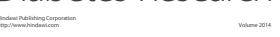

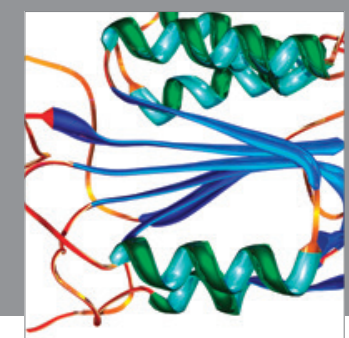

Disease Markers
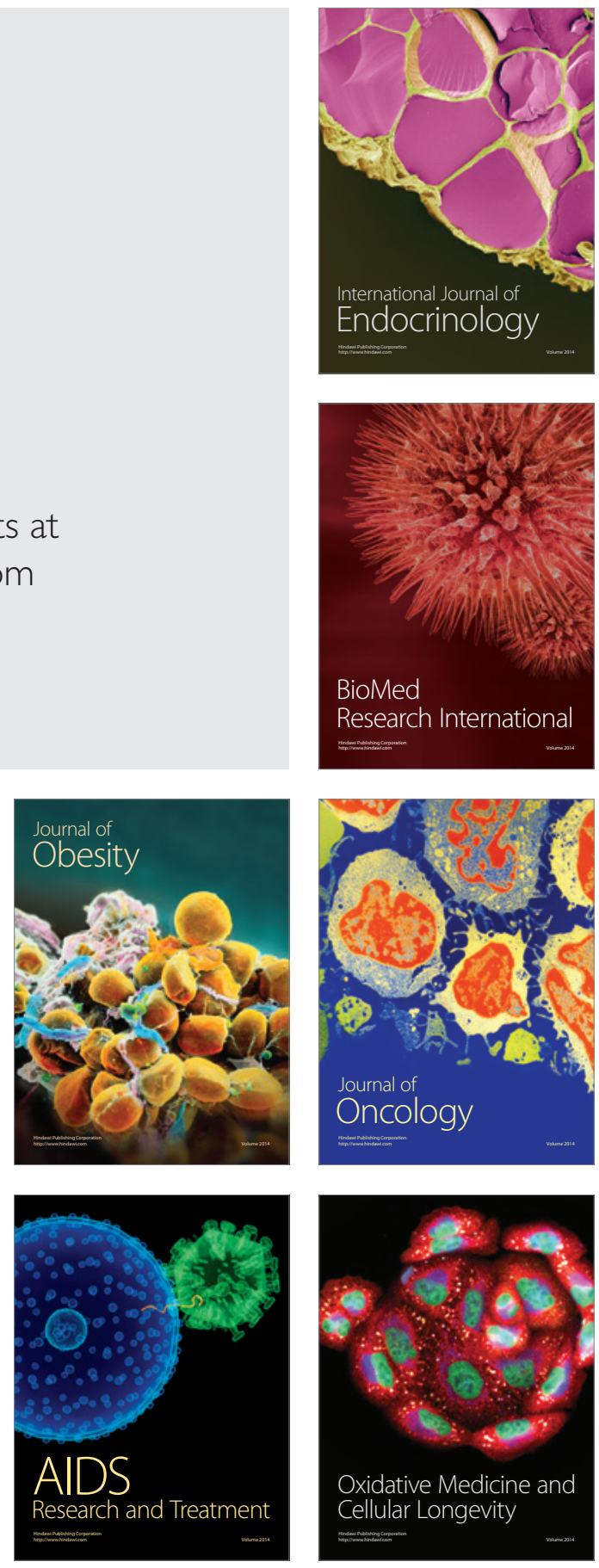